Economics Development Analysis Journal

\title{
Determinan Permintaan Uang Di Indonesia Tahun 2005.Q1-2014.QIV: Pendekatan ECM
}

\author{
Muhammad Hardeo Awang ${ }^{\bowtie}$
}

PT HM Sampoerna Tbk, Indonesia

\section{Info Artikel Abstrak}

Sejarah Artikel:

Diterima Januari 2016

Disetujui Maret 2016

Dipublikasikan Mei 2016

\section{Keywords:}

Money Demand M1, GDP,

CPI, Lending Rate, JCI
Penelitian ini bertujuan untuk menganalisis pengaruh variabel PDB, Indeks Harga Konsumen, Suku Bunga Pinjaman, Indeks Harga Saham Gabungan dan Nilai tukar (Kurs) terhadap Permintaan Uang (M1) di Indonesia. Hasil analisis menunjukkan bahwa dalam estimasi jangka pendek variabel PDB memiliki hubungan positif dan tidak signifikan terhadap permintaan uang (M1). Sementara dalam jangka panjang PDB memiliki hubungan positif dan signifikan terhadap permintaan uang (M1). Variabel IHK dalam jangka pendek memiliki hubungan positif dan tidak signifikan terhadap permintaan uang (M1). Sementara dalam jangka panjang IHK memiliki hubungan positif dan signifikan terhadap permintaan uang (M1). Variabel Suku bunga pinjaman dalam jangka pendek memiliki hubungan negatif dan signifikan terhadap permintaan uang (M1). Sementara dalam jangka panjang Suku bunga pinjaman memiliki hubungan negatif dan tidak signifikan terhadap permintaan uang (M1). Variabel IHSG dalam jangka pendek memiliki hubungan positif dan tidak signifikan terhadap permintaan uang (M1). Sementara dalam jangka panjang IHSG memiliki hubungan positif dan tidak signifikan terhadap permintaan uang (M1). Variabel Nilai tukar dalam jangka pendek memiliki hubungan positif dan tidak signifikan terhadap permintaan uang (M1). Sementara dalam jangka panjang Nilai tukar memiliki hubungan positif dan signifikan terhadap permintaan uang (M1).

\begin{abstract}
This study aimed to analyze the influence of variables GDP, Consumer Price Index, Lending Rate, JCI and the exchange rate to Demand Money (M1) in Indonesia in the short term and long term from 2005 to 2014. The analysis showed that in the short term estimates of GDP variable has a positive and significant relationship to the demand for money (M1). While in the long term GDP has a positive and significant relationship to the demand for money (M1). Variables CPI in the short term have a positive relationship and no significant effect on the demand for money (M1). While in the long term CPI has a positive and significant relationship to the demand for money (M1). The variable lending rate in the short term have a negative and significant relationship to the demand for money (M1). While long-term lending rate has a negative correlation and no significant effect on the demand for money (M1). JCI variable in the short term have a positive relationship and no significant effect on the demand for money (M1). While in the long term JCI has a positive and significant relationship to the demand for money (M1). Variable exchange rate in the short term have a positive relationship and no significant effect on the demand for money (M1). While in the long run exchange rate has a positive and significant relationship to the demand for money (M1).
\end{abstract}

(C) 2016 Universitas Negeri Semarang

\footnotetext{
Alamat korespondensi:

J1. Supriyadi No.9, Kalicari, Pedurungan, Kota Semarang, Jawa

Tengah 50198

E-mail: deo_awang34@yahoo.co.id
} 


\section{PENDAHULUAN}

Dalam perekonomian uang memiliki tiga fungsi: Sebagai alat tukar, satuan hitung, dan penyimpanan nilai. Tiga fungsi ini yang membedakan uang dengan aset aset lainnya dalam perekonomian. Sebagai alat pertukaran (medium of exchange), uang berarti sesuatu yang diberikan oleh pembeli kepada penjual ketika mereka membeli barang atau jasa. Sebagai satuan hitung (unit of account), uang berperan sebagai ukuran untuk menetapkan harga dan mencatat tagihan. Sebagai penyimpan nilai (store of value), uang merupakan alat yang dapat digunakan oleh masyarakat untuk mentransfer daya beli dari masa sekarang ke masa depan

Aset paling nyata yang dipegang oleh masyarakat adalah uang tunai baik uang kertas maupun uang logam yang beredar dalam masyarakat. Uang kartal adalah alat bayar yang sah dan wajib diterima oleh masyarakat dalam melakukan transaksi jual beli sehari-hari. Menurut undang-undang nomor 6 tahun 2009 tentang Bank Indonesia, adalah bahwa Bank Indonesia sebagai bank sentral di Indonesia, telah memiliki hak tunggal dalam mengeluarkan uang kartal ini. Sebagian besar kegiatan transaksi dalam perekonomian di suatu negara khusunya di indonesia menggunakan jenis uang kartal ini sebagai alat tukar yang sah. (Prasetyo 2012). Peranan uang dalam perekonomian sangat besar khususnya M1 (uang kartal \& giral ditambah demand deposit (tabungan \& deposito)) karena uang adalah media yang sangat vital dalam perekonomian masyarakat. Banyak atau sedikitnya jumlah uang yang beredar dalam masyarakat bergantung pada kondisi perekonomian. Berdasarkan teori Kuantitas Uang dari Milton Friedman (1956) bahwa jumlah uang beredar sangatlah penting untuk dijaga karena keterkaitannya terhadap inflasi dalam perekonomian sehingga jumlah uang beredar harus benar-benar dijaga kestabilannya agar tidak berdampak pada perekonomian. Peningkatan jumlah uang beredar yang melebihi kebutuhan untuk perekonomian akan mendorong masyarakat untuk melakukan spekulasi terhadap valuta asing yang dapat menimbulkan pelemahan nilai rupiah, sehingga peran uang M1 di masyarakat sangatlah penting.

Perkembangan jumlah M1 di masyarakat dari tahun ke tahun hingga sekarang terus mengalami peningkatan yang cukup besar, ini merupakan indikator bahwa semakin tingginya tingkat permintaan uang di masyarakat.

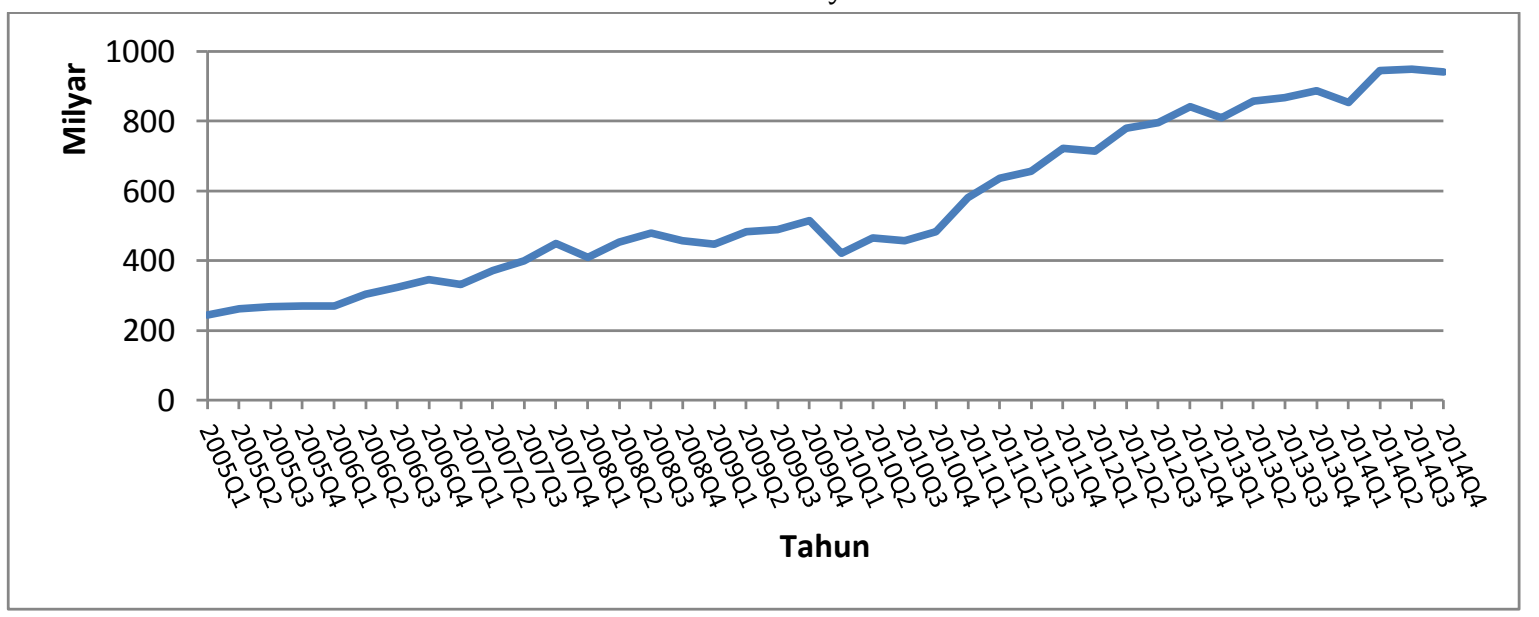

Gambar 1.1. Jumlah M1 di Masyarakat Indonesia Tahun 2005.Q1-2014.QIV

Sumber : Bank Indonesia, 2005

Pada Gambar 1.1 Jumlah uang kartal rill dari tahun ke tahun mengalami fluktuasi namun cendrung meningkat, peningkatan tertinggi sering terjadi pada kuartal terakhir dalam satu tahun tepatnya kuartal empat. Seperti yang telah diketahui tren peningkatan jumlah 
uang kartal rill di masyarakat juga di pengaruhi oleh budaya yang terjadi di masyarakat seperti adanya hari raya besar agama, libur panjang, dan akhir tahun adalah dimana saat-saat tersebut terjadi lonjakan permintaan uang kartal rill di masyarakat.

Peningkatan jumlah uang beredar yang tinggi akan berdampak pada kondisi perekonomian ini sesuai dengan banyak teori Kuantitas Uang salah satunya dari Milton Fridman yang mengatakan jika jumlah uang beredar ada pengaruh nyata terhadap inflasi yang terjadi dan berujung pada terjadinya gejolak perekonomian suatu negara, namun sebaliknya jika jumlah uang beredar terlalu sedikit atau kurang dari yang dibutuhkan dalam perekonomian akan berdampak pada lesunya kondisi perekonomian suatu negara tersebut. Ekspektasi inflasi merupakan elemen penting dalam analisis kebijakan moneter (Lei et al., 2015). Disinilah tugas Bank Indonesia sangat diperlukan sesuai dengan tujuan Bank Indonesia yaitu menjaga stabilitas nilai rupiah, baik jika dibandingkan dengan harga barang dalam negeri maupun jika di bandingkan dengan valuta asing, sesuai dengan tujuan tersebut Bank Indonesia berhak untuk mengatur atau mengelola besar moneter yang ada sesuai dengan yang dibutuhkan perekonomian.

\section{METODE PENELITIAN}

Jenis data yang digunakan dalam penelitian ini adalah data sekunder. Data sekunder adalah data yang diperoleh atau dikumpulkan oleh orang yang melakukan penelitian dari sumber-sumber yang telah ada. Data ini diperoleh dari Laporan tahunan Bank Indonesia, BPS dan BEI Data sekunder yang digunakan adalah data kuartalan selama kurun waktu 2005:1 sampai dengan tahun 2014:4 dengan jumlah 40 observasi.

Variabel yang digunakan dalam penelitian ini adalah:

(1). Variabel X ( Independent Variable/ Variabel Bebas) yaitu variabel yang mempengaruhi. Variabel bebasnya yaitu:
1. $\operatorname{PDB}\left(\mathrm{X}_{1}\right)$ : Pendapatan domestik bruto (PDB) yang digunakan adalah Produk Domestik Bruto Harga Berlaku

2. Indeks Harga Konsumen $\left(\mathrm{X}_{2}\right)$ : Suatu indeks, yang menghitung rata-rata perubahan harga dalam suatu periode, dari suatu kumpulan barang dan jasa yang dikonsumsi oleh penduduk/rumah tangga dalam kurun waktu tertentu, IHK di sini adalah proxy dari inflasi.

3. Suku Bunga Pinjaman $\left(\mathrm{X}_{3}\right)$ : Rata-rata dari seluruh suku bunga pinjaman bank umum yang ada di indonesia.

4. Indeks harga saham gabungan $\left(\mathrm{X}_{4}\right)$ : Indeks harga saham gabungan pada periode penutupan (end of period) yang di publikasikan dalam bentuk kuartalan.

(2) Variabel Control yaitu variabel yang membuat hubungan konstan antar variabel bebas dan terikat.

Nilai Tukar $\left(\mathrm{X}_{5}\right)$ : Nilai tukar rupiah jika dibandingkan dengan USD, diambil nilai kurs tengah nya antara kurs jual dan kurs beli.

(3). Variabel Y ( Dependent Variable/ Variabel Terikat) yaitu variabel akibat. Variabel terikatnya yaitu M1 (uang kartal \& giral serta demand deposit seperti tabungan dan deposito yang sifatnya mudah dicairkan).

Dalam penulisan penelitian ini, penulis menggunakan program eviews dalam pengolahan datanya. Metode analisis perhitungan yang digunakan untuk mengestimasi model penelitian adalah Error Correction Model-Engle Grenger (ECM-EG). Data time series seringkali tidak stationer sehingga menyebabkan hasil regresi meragukan atau disebut regresi lancung (spurious regression). Selanjutnya, data yang tidak stationer sering kali menunjukan hubungan ketidakseimbangan dalam jangka pendek, tetapi ada kecenderungan adanya hubungan keseimbangan dalam jangka panjang dan model paling tepat untuk data time series yang tidak stationer adalah model koreksi kesalahan. (Widarjono 2009). model yang akan dijadikan sebagai model penelitian yang dirumuskan dalam bentuk ECM-EG sebagai berikut. 
Model Jangka Panjang yaitu:

$\operatorname{lnM} 1_{t}=\alpha_{0}+\alpha_{1} \operatorname{lnPDB}{ }_{t}+\alpha_{2} \operatorname{lnSBP}_{t}+\alpha_{3} \operatorname{lnIHK}_{t}+$

$$
\begin{aligned}
& \alpha_{4} \mathrm{IHSG}_{\mathrm{t}}+\alpha_{5} \mathrm{Kurs}_{\mathrm{t}}
\end{aligned}
$$

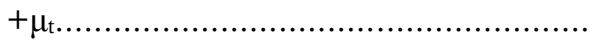

Model Koreksi Kesalahan Engle

Granger

$\Delta \operatorname{lnM} 1_{t}=\alpha_{0}+\alpha_{1} \Delta \ln \mathrm{PDB}_{\mathrm{t}}+\alpha_{2} \Delta \operatorname{lnSBP_{\mathrm {t}}}+\alpha_{3} \Delta \mathrm{IHK}_{\mathrm{t}}$ $+\alpha_{4} \Delta \mathrm{IHSG}_{\mathrm{t}}+\alpha_{5} \Delta \mathrm{NT}_{\mathrm{t}}+\mathrm{EC}_{\mathrm{t}}$

Keterangan :

M1 = Uang kartal dan giral ditambah demand deposit (Milyar Rupiah)

PDB = Pendapatan Domestik Bruto Harga Berlaku (Milyar Rupiah)
IHK

SBP

IHSG

NT

$\ln$

$\alpha_{0,}, \alpha_{1}, \alpha_{2}, \alpha_{3}, \alpha_{4}, \alpha_{5}=$ Parameter, $\Delta$ adalah Delta

ECt adalah Error Correction Term.

\section{HASIL DAN PEMBAHASAN}

\section{Hasil Pengujian ECM-EG}

Setelah melakukan estimasi model ECM-EG tersebut, didapatkan hasil regresi jangka pendek dapat dilihat pada tabel 1 :

Tabel 1. Hasil Regresi Jangka Pendek Error Correction Model-EG

\begin{tabular}{lccc}
\hline Variabel & Koefisien & t-statistik & Probabilitas \\
\hline$\Delta \operatorname{lnPDB}$ & 0.137337 & 0.374813 & 0.7103 \\
$\Delta \mathrm{IHK}$ & 0.000519 & 0.448006 & 0.6572 \\
$\Delta$ Suku bunga & -0.039833 & $-2.081882^{*}$ & $0.0434^{*}$ \\
pinjaman & & $(2.021)$ & 0.9720 \\
$\Delta \mathrm{IHSG}$ & 1.000073 & -0.033527 & 0.3569 \\
$\Delta \mathrm{lnNT}$ & 0.244732 & 0.934878 & 0.1593 \\
$\mathrm{C}$ & 0.027737 & 1.440739 & 0.0004 \\
$\mathrm{ECT}$ & -0.604169 & -3.978668 & \\
$\mathrm{R}^{2}$ & & 0.382295 & \\
Adjusted $R^{2}$ & & 0.266476 & \\
DW-Stat & & 1.75033 & \\
F-Statistic & & 3.300782 & \\
$\mathrm{~T}-$-Tabel & & 2.021 & \\
\hline
\end{tabular}

Sumber: Hasil Olahan Eviews

*signifikan pada tingkat $\alpha=5 \%$

$$
\begin{aligned}
\Delta \operatorname{lnM} 1_{\mathrm{t}}= & 0.027737+0.137337 \Delta \ln \operatorname{lDB}_{\mathrm{t}}+ \\
& 0.000519 \Delta \operatorname{lnIHK}_{\mathrm{t}}-0.039833 \Delta \operatorname{lnSBP}_{\mathrm{t}} \\
& +1.000073 \Delta \mathrm{IHSG}_{\mathrm{t}}+0.244732 \Delta \mathrm{NT}_{\mathrm{t}}- \\
& 0.604169 \mathrm{ECT}_{\mathrm{t}-1}+\mu_{\mathrm{t}} \ldots \ldots \ldots \ldots \ldots \ldots . .(3)
\end{aligned}
$$

Model ECM-EG ini dikatakan valid jika

tanda koefisien koreksi kesalahan (ECT) bertanda negatif dan signifikan secara statistik (Widarjono 2009).

Berdasarkan hasil estimasi pada Tabel 1 diketahui bahwa nilai ECT signifikan pada $\alpha=$
5\% dengan nilai koefisien sebesar - 0.604169 yang berarti bahwa model ECM-EG ini sah digunakan dan mampu mengkoreksi ketidakseimbangan dalam jangka pendek ke dalam keseimbangan jangka panjangnya sebesar $60.4 \%$.

Selanjutnya, didapatkan hasil regresi jangka panjang dapat dilihat pada tabel 2 dibawah ini : 
Tabel 2. Hasil Regresi Jangka Panjang Error correction model-EG

\begin{tabular}{cccc}
\hline Variabel & Koefisien & t-statistik & Probabilitas \\
\hline InPDB & 0.810921 & $\begin{array}{c}8.643066^{*} \\
(2.021)\end{array}$ & $0.0000^{*}$ \\
& & $2.716806^{*}$ & \\
IHK & 0.002867 & $(2.021)$ & $0.0103^{*}$ \\
Suku bunga & -0.029117 & 1.872179 & 0.0698 \\
pinjaman & 2.00001 & 0.628616 & 0.5341 \\
IHSG & 0.468874 & 3.445313 & $0.0015^{*}$ \\
lnNT & -2.694313 & $(2.021)$ & 0.1182 \\
C & & 1.602991 & \\
$\mathrm{R}^{2}$ & & 0.971095 & \\
Adjusted $R^{2}$ & & 0.966844 & \\
DW-Stat & & 1.124932 & \\
F-Statistic & & 228.4520 & \\
T-Tabel & & 2.021 &
\end{tabular}

Sumber: Hasil Olahan Eviews

*signifikan pada tingkat $\alpha=5 \%$

\section{Pengaruh Produk Domestik Bruto (PDB) terhadap M1}

Variabel PDB pada estimasi jangka panjang memiliki nilai koefisien sebesar 0.810921 artinya setiap peningkatan PDB sebesar $1 \%$ akan menyebabkan peningkatan permintaan uang M1 di Indonesia sebesar $0.810921 \%$, ceteris paribus. Hal ini sesuai dengan teori Kuantitas Uang dari Milton Friedman bahwa hubungan antara PDB dan permintaan uang adalah positif, selanjutnya didukung dengan nilai t-statistik $8.643066>$ 2,021, sehingga dapat disimpulkan variabel PDB dalam jangka panjang berpengaruh terhadap permintaan uang di Indonesia atau Ha diterima, ini sejalan dengan penelitian Sidiq (2005), Yu dan Gan (2009), Achsani (2010), dan Hayati (2011).

Variabel PDB pada estimasi jangka pendek memiliki nilai koefisien sebesar 0.137337 artinya setiap peningkatan PDB sebesar $1 \%$ akan menyebabkan penurunan permintaan uang M1 di Indonesia sebesar $0.137337 \%$, ceteris paribus. Hal ini tidak sesuai teori Kuantitas Uang dari Milton Friedman bahwa hubungan antara PDB dan permintaan uang adalah positif, selanjutnya nilai t-statistik $0.374813<2,021$, sehingga dapat disimpulkan variabel PDB dalam jangka pendek tidak berpengaruh terhadap permintaan uang di
Indonesia atau $\mathrm{Ha}$ ditolak, ini sejalan dengan penelitian Hayati (2011) dan Setiadi (2013).

\section{Pengaruh IHK terhadap M1}

Variabel IHK pada estimasi jangka panjang memiliki nilai koefisien sebesar 0.002867 artinya setiap peningkatan IHK sebesar $1 \%$ akan menyebabkan peningkatan permintaan uang M1 di Indonesia sebesar $0.002867 \%$, ceteris paribus. Hal ini sesuai dengan teori Kuantitas Uang dari Milton Friedman bahwa hubungan antara IHK dan permintaan uang adalah positif, selanjutnya didukung dengan nilai t-statistik $2.716806>$ 2,021, sehingga dapat disimpulkan variabel IHK dalam jangka panjang berpengaruh terhadap permintaan uang di Indonesia atau Ha diterima, ini sejalan dengan penelitian Hayati (2011) dan Setiadi (2013).

Variabel IHK pada estimasi jangka pendek memiliki nilai koefisien sebesar 0.000519 artinya setiap peningkatan IHK sebesar $1 \%$ akan menyebabkan peningkatan permintaan uang M1 di Indonesia sebesar $0.000519 \%$, ceteris paribus. $\mathrm{Hal}$ ini sesuai dengan teori Kuantitas Uang dari Milton Friedman bahwa hubungan antara IHK dan permintaan uang adalah positif, selanjutnya nilai t-statistik $0.448006<2,021$, sehingga dapat disimpulkan variabel IHK dalam jangka pendek tidak berpengaruh terhadap permintaan uang di 
Indonesia atau $\mathrm{Ha}$ ditolak, ini sejalan dengan penelitian Bassey (2012).

\section{Pengaruh Suku Bunga Pinjaman terhadap M1}

Variabel suku bunga pinjaman pada estimasi jangka panjang memiliki nilai koefisien sebesar -0.029117 artinya setiap peningkatan Suku bunga pinjaman sebesar $1 \%$ akan menyebabkan penurunan permintaan uang M1 di Indonesia sebesar $0.029117 \%$, ceteris paribus. Hal ini sesuai dengan teori Kuantitas Uang dari Milton Friedman bahwa hubungan antara suku bunga dan permintaan uang adalah negatif, selanjutnya nilai t-statistik $1.87219<2,021$, sehingga dapat disimpulkan variabel suku bunga pinjaman dalam jangka pendek tidak berpengaruh terhadap permintaan uang di Indonesia atau Ha ditolak.

Variabel suku bunga pinjaman pada estimasi jangka pendek memiliki nilai koefisien sebesar -0.039833 artinya setiap peningkatan Suku bunga pinjaman sebesar $1 \%$ akan menyebabkan penurunan permintaan uang M1 di Indonesia sebesar $0.039833 \%$, ceteris paribus. Hal ini sesuai dengan teori Kuantitas Uang dari Milton Friedman bahwa hubungan antara suku bunga dan permintaan uang adalah negatif, selanjutnya nilai t-statistik $2.081882>2,021$, sehingga dapat disimpulkan variabel Suku bunga pinjaman dalam jangka pendek berpengaruh terhadap permintaan uang di Indonesia atau $\mathrm{Ha}$ diterima, ini sejalan dengan penelitian Aliasudin (2010), Hayati (2011), dan Bassey (2012).

\section{Pengaruh Indeks Harga Saham Gabungan terhadap M1}

Variabel IHSG pada estimasi jangka panjang memiliki nilai koefisien sebesar 2.00001 artinya setiap peningkatan IHSG sebesar $1 \%$ akan menyebabkan penurunan permintaan uang M1 di Indonesia sebesar $2.00001 \%$, ceteris paribus. Hal ini tidak sesuai dengan teori Kuantitas Uang dari Milton Friedman bahwa hubungan antara harga saham dan permintaan uang adalah negatif, selanjutnya nilai t-statistik 0.628616 < 2,021, sehingga dapat disimpulkan variabel IHSG dalam jangka panjang tidak berpengaruh terhadap permintaan uang di Indonesia atau $\mathrm{Ha}$ ditolak.

Variabel IHSG pada estimasi jangka pendek memiliki nilai koefisien sebesar 1.000073 artinya setiap peningkatan IHSG sebesar $1 \%$ akan menyebabkan penurunan permintaan uang M1 di Indonesia sebesar $1.000073 \%$, ceteris paribus. Hal ini tidak sesuai dengan teori Kuantitas Uang dari Milton Friedman bahwa hubungan antara harga saham dan permintaan uang adalah negatif, selanjutnya nilai t-statistik $0.033527<$ 2,021, sehingga dapat disimpulkan variabel IHSG dalam jangka pendek tidak berpengaruh terhadap permintaan uang di Indonesia atau $\mathrm{Ha}$ ditolak.

\section{Pengaruh Nilai Tukar terhadap M1}

Variabel Nilai Tukar pada estimasi jangka panjang memiliki nilai koefisien sebesar 0.468874 artinya setiap peningkatan Nilai Tukar 1\% akan menyebabkan peningkatan permintaan uang M1 di Indonesia sebesar $0.468874 \%$, ceteris paribus. Selanjutnya nilai t-statistik $3.445313>2,021$, sehingga dapat disimpulkan variabel Nilai Tukar dalam jangka panjang berpengaruh terhadap permintaan uang di Indonesia atau Ha diterima, hal ini sejalan dengan penelitian Sidiq (2005).

Variabel Nilai Tukar pada estimasi jangka panjang memiliki nilai koefisien sebesar 0.468874 artinya setiap peningkatan Nilai Tukar 1\% akan menyebabkan peningkatan permintaan uang M1 di Indonesia sebesar $0.468874 \%$, ceteris paribus. Selanjutnya nilai t-statistik $3.445313>2,021$, sehingga dapat disimpulkan variabel Nilai Tukar dalam jangka panjang berpengaruh terhadap permintaan uang di Indonesia atau Ha diterima, hal ini sejalan dengan penelitian Sidiq (2005).

\section{SIMPULAN}

Penelitian ini bertujuan untuk menganalisis pengaruh variabel PDB, Indeks Harga Konsumen, Suku Bunga Pinjaman, Indeks Harga Saham Gabungan dan Nilai tukar (Kurs) terhadap Permintaan Uang (M1) di Indonesia. Hasil analisis menunjukkan bahwa dalam estimasi jangka pendek variabel PDB memiliki hubungan positif dan tidak signifikan terhadap permintaan uang (M1). Sementara dalam jangka 
panjang $\mathrm{PDB}$ memiliki hubungan positif dan signifikan terhadap permintaan uang (M1). Variabel IHK dalam jangka pendek memiliki hubungan positif dan tidak signifikan terhadap permintaan uang (M1). Sementara dalam jangka panjang IHK memiliki hubungan positif dan signifikan terhadap permintaan uang (M1) Variabel Suku bunga pinjaman dalam jangka pendek memiliki hubungan negatif dan signifikan terhadap permintaan uang (M1). Sementara dalam jangka panjang Suku bunga pinjaman memiliki hubungan negatif dan tidak signifikan terhadap permintaan uang (M1). Variabel IHSG dalam jangka pendek memiliki hubungan positif dan tidak signifikan terhadap permintaan uang (M1). Sementara dalam jangka panjang IHSG memiliki hubungan positif dan tidak signifikan terhadap permintaan uang (M1). Variabel Nilai tukar dalam jangka pendek memiliki hubungan positif dan tidak signifikan terhadap permintaan uang (M1). Sementara dalam jangka panjang Nilai tukar memiliki hubungan positif dan signifikan terhadap permintaan uang (M1).

\section{DAFTAR PUSTAKA}

Achsani, Noer. 2010. Stability of Money Demand in an Emerging Market Economy: An Error Correction and ARDL Model for Indonesia. Journal of International Studies. Bogor: Institut Pertanian Bogor.

Aliasuddin. 2012. Pengujian Elastisitas Harga Pada Permintaan Uang di Indonesia. Majalah Ekonomi tahun XXII. Banda Aceh: Universitas Syiah Kuala Darussalam

Bank Indonesia. 2015. Laporan Tahunan Bank Indonesia.

http://www.bi.go.id/id/publikasi/laporantah unan/perekonomian/Default.aspx. September 2015)

Bassey. 2012. The Effect Of Monetary Policy On Demand for Money In Nigeria. Interdeciplinary Journal Of Contemporary Research In Business. Nigeria: University of Calabar.

Hayati, Isra. 2011. Analisis Permintaan dan Penawaran Uang di Indonesia. QE Journal Vol 02-No.01-08. Medan: Universitas Negeri Medan.
Kholisudin, A. (2012). Determinan Permintaan Kredit Pada Bank Umum di Jawa Tengah 2006-2010. Economics Development Analysis Journal, 1(1).

Lei, C., Lu, Z. \& Zhang, C., 2015. News On Inflation And The Epidemiology Of Inflation Expectations In China. Economic System, 39, pp.644 - 653.

Mankiw, Gregory. 2006. Teori Makroekonomi Edisi 5. Jakarta: Erlangga.

Oni Setiadi, I. (2013) Analisis Faktor-Faktor yang Mempengaruhi Permintaan Uang di Indonesia Tahun 1999 : Q1 - 2010 : Q4 dengan Pendekatan Error Corecrion Models (Ecm). Economics Development Analysis Journal, 2(1).

Prasetyo, P.Eko. 2012. Buku Ajar Makro Ekonomi. Yogyakarta: Beta Offset.

Sidiq, Sahabudin. 2005. Stabilitas Permintaan Uang Di Indonesia : Sebelum dan Sesudah Perubahan Sistem Nilai Tukar. Jurnal Ekonomi Pembangunan. Yogyakarta: Universitas Islam Indonesia.

Ulfa, S. (2012). Pengaruh Jumlah Uang Beredar(JUB), Suku Bunga Sertifikat Bank Indonesia (Sbi), Impor, Ekspor Terhadap Kurs Rupiah/ Dollar Amerika Serikat Periode Januari 2006 Sampai Maret 2010. Economics Development Analysis Journal, 1(1).

Widarjono, Agus. 2009. Ekonometrika Pengantar dan Aplikasi. Yogyakarta: PT Ekonisia Kampus FE UII.

Yu dan Gan. 2009. Empirical analysis of the Money Deman Function in ASEAN-5. International Research Journal of Finance and Economics. China: Guizhou Collage of Finance and Economics guiyang. 